\title{
POR SUS OBRAS LOS CONOCERÉIS. DOCUMENTOS DE PERPETRADOR Y VOCES DE VÍCTIMAS EN RETRATOS DE IDENTIFICAÇÃO (ANITA LEANDRO, 2014)
}

\section{You Will Recognize Them by Their Fruits. Perpetrator documents and victim voices in Portraits of Identification (Anita Leandro, 2014)}

\author{
Vicente Sánchez-Biosca* \\ Universitat de València
}

\section{Palabras clave}

Tortura Imágenes de perpetrador Documental Dictadura brasileña

\section{Keywords}

Torture Perpetrator images Documentary Brazilian Dictatorship
RESUMEN: En los últimos años, el estudio de los perpetradores de violencia de masas ha crecido sustancialmente en publicaciones académicas, museos, memorias y cobertura mediática. Lo ha hecho cada vez con menos dependencia respecto a los influyentes y muy avanzados Holocaust Studies. Además, los horizontes de la investigación se han ampliado desde las personalidades y la maquinaria de destrucción al estudio más cercano de los documentos, objetos y mirada de los perpetradores. Es en este dominio donde se inscribe Retratos de identificação de Anita Leandro (2014), film que, nacido de la investigación histórica, se propone reescribir mediante el uso de la composición y el montaje los documentos visuales y materiales de los perpetradores del primer caso difundido públicamente de tortura en Brasil en 1969. Poniendo a dialogar testimonios presentes, films militantes de los años setenta, fotografías policiales de fichaje e incluso la autopsia de un prisionero muerto bajo tortura, Anita Leandro se incorpora a esa corriente del documental cinematográfico que, en la línea de Harun Farocki o Chris Marker, consiste en interrogar y analizar las imágenes por medio de las imágenes mismas.

ABSTRACT: In recent years, the study of perpetrators of mass violence has grown substantially in academic publications, museums, memoirs, and the media. This has been done beyond the dependence on the influential and highly developed Holocaust Studies. In addition, the horizons of this research field have broadened from the analysis of singular personalities and the destruction machinery to the closer study of the documents, objects and the gaze of the perpetrators. It is in this domain that a film such as Portraits of Identification by Anita Leandro (2014) is inscribed. The documentary, born of its author's historical research, rewrites the visual and material documents of the perpetrators of the first publicly reported case of torture in Brazil in 1969 through the use of editing and montage. By bringing together present testimonies, militant films from the 1970s, police photographs and the autopsy of a prisoner who died under torture, Anita Leandro joins this trend of film documentary that, in the wake of Harun Farocki and Chris Marker, consists in interrogating and analyzing the images by means of other images.

1 Este texto se enmarca en los proyectos de investigación «Representaciones Contemporáneas del Perpetrador de Violencias de Masas: Conceptos, Relatos e Imágenes» (HAR2017-83519-P) y «De espacios de perpetración a lugares de memoria. Formas de representación» (PROMETEO/2020/059). Vaya por delante mi máximo agradecimiento a Anita Leandro por una larga y generosa entrevista celebrada en Rio de Janeiro el 27 noviembre de 2016, seguida por sus comentarios, respuestas puntuales y detalladas a cuantas cuestiones le he ido planteando a lo largo de estos años. Asimismo, estoy en deuda con mi amigo Eduardo Morettin, gran especialista a la vez del cine y de la historia, que leyó cuidadosamente este texto y comentó y ayudó a corregir algunos puntos del mismo. Sin ellos, y los comentarios de los anónimos evaluadores de la revista, este artículo jamás habría sido escrito.

* Correspondencia a / Correspondence to: Vicente Sánchez-Biosca. Departamento Teoría de los Lenguajes y Ciencias de la comunicación. Universitat de València. Avda. Blasco lbáñez 32 (46010 Valencia). - vicente.sanchez@uv.es - http://orcid.org/0000-0002-4053-4440.

Cómo citar / How to cite: Sánchez-Biosca, Vicente (2021). «Por sus obras los conoceréis. Documentos de perpetrador y voces de víctimas en Retratos de identificação (Anita Leandro, 2014)». Papeles del CEIC, vol. 2021/2, papel 251, 1-19. (http://doi.org/10.1387/pceic.22728).

Fecha de recepción: abril, 2021 / Fecha aceptación: junio, 2021

ISSN 1695-6494 / ㄷ 2021 UPV/EHU 


\section{EXPOSICIÓN DE MATERIALES: EL ALIENTO DEL PERPETRADOR}

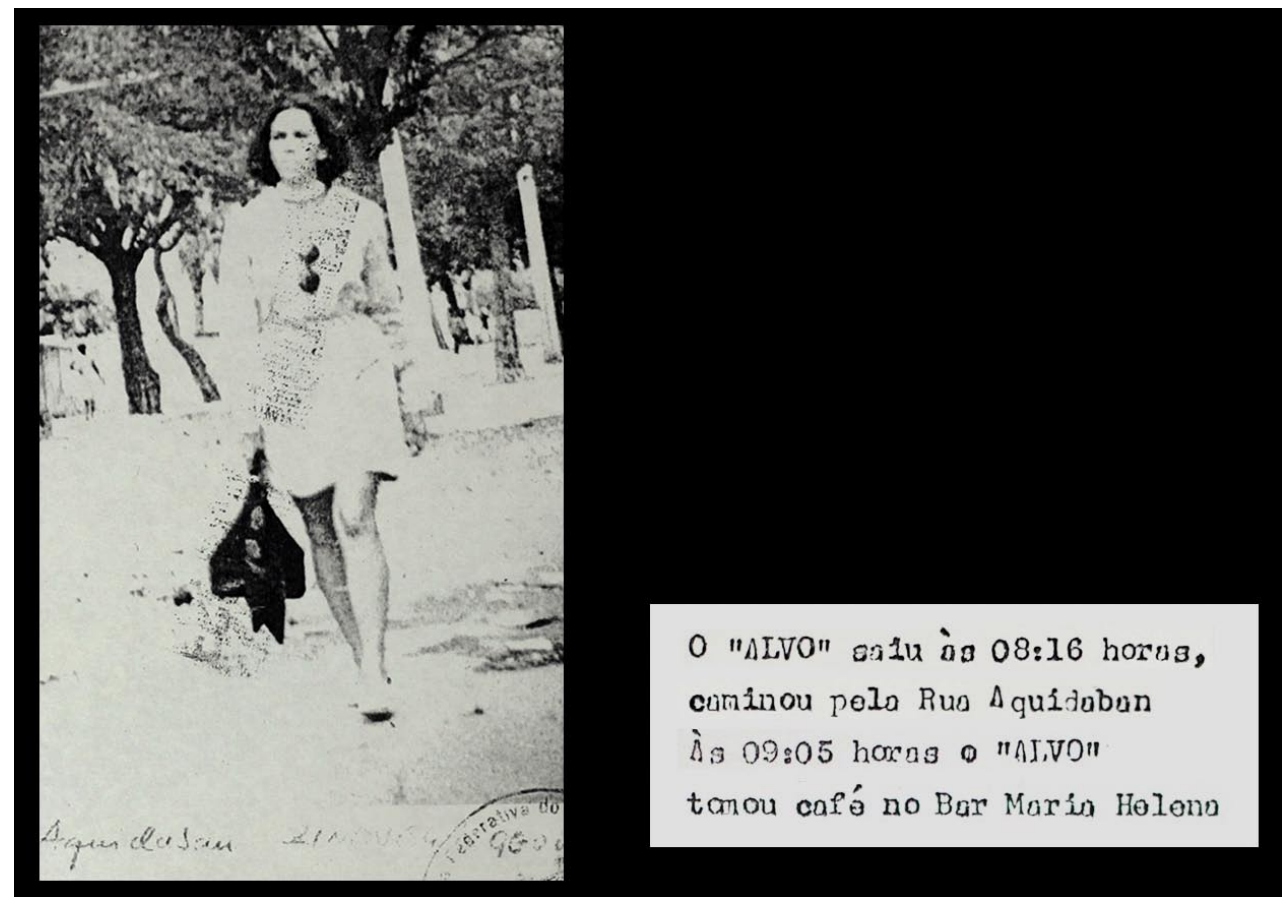

Figura 1

Fotograma de la secuencia inicial de Retratos de identificação (Anita Leandro, 2014)

Junto a una nota mecanografiada, clasificada bajo la rúbrica "Operação "Bis"», se deja leer el sello "Confidencial». Es el escueto informe de un agente de vigilancia, fechado el 21 de noviembre de 1969, que cubre varias horas de atenta observación y seguimiento: entre las seis y las veinte horas de esa jornada. Un sonido de fondo sugiere exteriores callejeros, paso de vehículos. La fotografía muestra una mujer joven, de cuerpo entero, caminando por un parque, tomada en ligero contrapicado. Al lado de la foto, una nota comenta: "o alvo", es decir, el objetivo, el blanco, "salió a las 8:16 horas, caminó por la calle Aquidaban. A las 9:05 horas (...) tomó café en el bar Maria Helena». Tras una pantalla en negro, un plano frontal captado desde muy cerca se acompaña de otra nota: "a las 9:30, el «objetivo" dio dos rodeos, tomó el ómnibus de la línea Meyer-Copacabana, bajó a las 10:18 en Candelaria». Una tercera instantánea la capta de perfil, en un plano americano, también resaltado por un comentario en idéntico soporte: «Regresó o entró por la Avenida Rio Branco a las 10:30, subió a un ferry para Niteroi a las 11:00 horas tomó un aperitivo en City-Niteroi». Cuarta foto, de perfil opuesto a la anterior, con el comentario: "preguntó la dirección de la autoescuela, el precio del billete sería de 150,00 NCR\$». Quinta foto, cortada por la derecha y en plano medio: el rostro de la muchacha aparece aquí nítidamente por vez primera. Su gesto es serio. Comentario en ficha adjunta: "se dirigió a la Autoescuela San Jorge siguiendo un rumbo desconocido". Mientras esta imagen y este texto permanecen en pantalla, una voiceover se deja oír al fondo superponiéndose a los sonidos de la calle: «Fui detenida en la noche del 21 de noviembre de 1969....².

2 Esta secuencia de fotocopias, procedente de los archivos nacionales y del Superior Tribunal Militar, llegó a manos de la directora, Anita Leandro, cuando el film estaba casi concluido. Leandro decidió ubicarla de acuerdo 
La voz de la mujer en primera persona introduce un salto temporal respecto a la secuencia que acabamos de contemplar, pero, al mismo tiempo, permite saber que esos documentos fotográficos la representan a ella y han sido robados por quienes le pisaban los talones y la acechaban durante ese aciago día. Sus minuciosos autores eran agentes secretos de la policía. Estos estamparon sus comentarios y dejaron el resto de la acción a sus compañeros ${ }^{3}$. Estas fotografías contienen algo siniestro: son imágenes de perpetrador ${ }^{4}$, pues encarnan la mirada de quienes planeaban la acción violenta sobre la joven y captan - y en cierto modo contribuyen a tipificar o confirmar la imagen de- un enemigo. Pero, además, estas imágenes, interpretadas desde la detención, anuncian una inminencia, incorporándose a ese género que tan certeramente analizó Barbie Zelizer (2010) en casos que tendrían resultados letales y que denominó «imágenes de muerte inminente» (images of impending death). Poseen, pues, una potencia inquietante, como si profetizasen una violencia que no llegaremos a percibir en nuestro caso sino a través de la palabra testimonial de quienes la sufrieron. La escasa distancia desde la que el disimulado dispositivo fotografió a la despreocupada muchacha, el minucioso seguimiento, la sistematicidad con la que ofrece una secuencia de la jornada de su "caída" se unen a la vocación performativa de estas fotografías: están abocadas a la acción; más exactamente, la provocan ${ }^{5}$. No menos elocuente es su lenguaje funcional, su estilo depurado, cronístico: desprovisto de adjetivación, ni siquiera parecen haberse molestado sus autores en calificar ofensivamente al enemigo. Nada define mejor el relato de estos precursores de la violencia que el término que la despersonaliza ("o alvo») y le atribuye un lugar en la acción que está a punto de desencadenarse ${ }^{6}$.

La secuencia que irrumpe a continuación responde a otras coordenadas. La voz de la mujer que menciona su detención precede a su imagen. Mirando frontalmente a la cámara, interpelando incluso al objetivo en un plano medio corto, refiere los detalles de su captura. El film de archivo del que surge es de un austero blanco y negro propio del estilo militante de los años sesenta y setenta ${ }^{7}$. El metraje la acoge en su seno de una manera muy distinta a como lo hicieron las instantáneas amenazantes de sus enemigos. Aquí ella testimonia ante una cámara acogedora, que se comporta como una auténtica camarada. Dora (María Auxiliadora Lara Barcelos), pues así se llama, se dirige a la cámara de Luiz Alberto Sanz, militante del grupo brasileño Vanguardia Popular Revolucionaria (VPR), que formaba parte del mismo contin-

con su cronología como secuencia de apertura de su documental, expresando así su voluntad de análisis y deconstrucción de la palabra y los archivos de los represores (entrevista con la directora citada).

3 La práctica en cuestión de vigilancia de comunistas se remontaba a los años 1930, como señala Motta (2011: 334) y fue seguida e incrementada por la policía desde el golpe de 1964. Los «terroristas» tomarian el relevo en el discurso policíaco a partir de entonces.

4 Marianne Hirsch fue pionera en detectar este género enunciativo de imágenes, como aquellas que «ilustran la calidad de la mirada del perpetrador, así como la conexión de esta con sus actos» (Hirsch, 2001: 25-26), de tal manera que, al ver a través de sus ojos, nos es imposible como espectadores distanciarnos de ellos. Para un estudio metodológico de esta categoría de imágenes en toda su complejidad, véase Sánchez-Biosca (2021).

5 Muchas funciones tenían estas imágenes: «Las fotografías servían (...) como invitación a la delación e instrumento de control, humillación y amedrentamiento» ("As fotografías de polícia serviam (...) com convite à delação e instrumento de controle, humilhação e amedrontamento» (Leandro, 2016: 105).

6 Luciana Lombardo Costa Pereira (2014: 256) describe con precisión la lógica interna de los órganos de represión de la dictadura, demostrando que la producción del archivo pone de manifiesto la intencionalidad y finalidades políticas

7 Recuérdese que el cortometraje que Chris Marker dedicó a la tortura en Brasil data de 1970 y es pionero, pues se refiere a un acontecimiento que tuvo lugar en septiembre de 1969 (dos meses antes del que constituye el objeto de la investigación de Leandro): On vous parle du Brésil: Tortures. En él, los 15 prisioneros canjeados por un embajador norteamericano hablan, desde Cuba, sobre las torturas sufridas. 
gente de setenta personas que fueron liberadas por la dictadura brasileña como canje por el embajador suizo Giovanni Bucher, que había sido secuestrado por la guerrilla. Las imágenes datan de la llegada de los recién liberados a Santiago de Chile, a la sazón bajo el gobierno de la Unidad Popular de Salvador Allende, y pertenecen al film dirigido por Sanz en colaboración con Pedro Chaskel bajo el título No es hora de llorar, un producto montado con urgencia en razón del valor que contenían los testimonios de estas víctimas de la tortura. Rodadas el 20 de enero de 1971 en la Universidad de Santiago, estas sobrias imágenes ostentan una marca de militancia en su mismo interior: en la casi desnuda pared del fondo se deja ver un póster que representa al capitán del ejército brasileño Carlos Lamarca, desertor del cuerpo militar al que pertenecía para pasar a liderar la lucha armada contra la dictadura ${ }^{8}$. Atrincherado en el contracampo, pero visible para Dora, su camarada Sanz obtiene este relato en caliente y formula cuestiones de acuerdo con un imperativo testimonial. En cierto modo, nos hallamos ante una inversión del dispositivo que gobernaba las imágenes de perpetrador precedentes sobre el mismo personaje. La voz interrogativa de Sanz fuera de campo confirma que Dora forma con él y con el dispositivo un todo coherente (recuérdese el póster de Lamarca al fondo, cerrando solidariamente el círculo), bien ensamblado emocional e ideológicamente 9 .

Un nuevo cambio de registro sucede a continuación: un documento policial, en sintética prosa, condensa el final de la operación de captura de los "terroristas» que formaban el comando, en número de tres: Chael Charles Schreier, Antônio Roberto Espinosa y la citada María Auxiliadora Lara Barcelos. Sobre la imagen de dicho documento, una voz masculina relata con exactitud cómo transcurrió el asalto policial al piso franco donde se ocultaban viviendo como pareja Dora y Espinosa y teniendo oculto a Chael, miembros todos ellos del grupo de guerrilla urbana Vanguarda Armada Revolucionária (VAR-Palmares), detuvo a sus integrantes, se incautó de documentación y armas y procedió a torturarlos en dos lugares distintos. Este testigo y protagonista se dirige a Anita Leandro, muchos años más tarde, en 2013, introduciendo así una tercera capa temporal en la acción. Ese hombre es uno de ellos, Antônio, comandante de la organización en el tiempo de los hechos y único superviviente de la tragedia, aunque de momento el espectador desconoce este dato. Su condición actual de profesor y la distancia de cuatro décadas que lo separa de los hechos le permiten una enunciación retrospectiva muy distinta de los discursos anteriores, pegados a la inmediatez, aunque fuertemente orgánica, como luego veremos.

Así pues, en poco más de tres minutos, Retratos de Identificação ${ }^{10}$ ha logrado desplegar una compleja variedad de documentos e imágenes, tanto en lo que respecta a su soporte, como a su enunciación personal, espacial y temporal; tres ejes que permiten analizar las imágenes en relación con su pragmática, su contenido y su recepción. Todo ello, por otra parte, se ha logrado a condición de la renuncia a una voz conductora omnisciente, lo que confirma la con-

8 Véanse datos al respecto en Machado (2017: 214 y ss.). La imagen de Carlos Lamarca es fundamental en esta escena. Fue él quien lideró el grupo que secuestró a Bucher en la ciudad de Río de Janeiro en 1970, gracias a lo cual Dora, Sanz y otros 68 presos políticos fueron canjeados y liberados, de modo que es una suerte de homenaje y a la vez un signo de camaradería por parte de Sanz. Perseguido, sería asesinado el 17 de setiembre de 1971.

9 El film de 36 minutos de duración es un auténtico manifiesto, pues, además de recoger testimonios de las víctimas, reconstruye escenas de tortura y se cierra con un reforzamiento de la conciencia revolucionaria por parte de los militantes, coronado por la llegada del avión de Varig al aeropuerto de Pudahuel en Santiago el 14 de enero de 1971.

10 Sintomáticamente, Leandro escoge como título de su documental - Retratos de identificação- el término técnico utilizado por la policía brasileña para designar esas fotos de identificación que en inglés se denominan "forensic photos». Mediante ese gesto, confirma su decisión de partir y deconstruir el dispositivo policial en todos sus aspectos. 
fianza que la autora deposita en la elocuencia de los documentos hallados. Estos tres cortes históricos - el tiempo de la tortura y la muerte, el tiempo de la libertad y la denuncia desde el exilio y el tiempo de la memoria retrospectiva - retornarán a lo largo del film superponiéndose y complejizándose gracias a la intervención de un nuevo personaje. Les jeux sont faits, podríamos decir: imagen y crónica de perpetrador, testimonio-denuncia a través del material de archivo, testimonio audiovisual retrospectivo.

\section{EL PESO DE LA MATERIA: ESOS OBJETOS FOTOGRÁFICOS}

Este arranque del film confirma una decidida apuesta por la imagen de archivo y su articulación con el testimonio. Mas el término "archivo» debe ser entendido aquí como el producto material, rescatado del olvido y dispuesto según un orden inteligible, de una investigación realizada en repositorios dispersos, caóticos, pues, una vez que las piezas habían servido a su labor (cazar y exterminar a los enemigos), su valor se volatilizaba y el extravío, abandono y/o destrucción de documentos fueron frecuentes, por pérdida de funcionalidad o para garantizar la impunidad de sus autores. Anita Leandro dedicó cuatro años a una investigación - léase esta expresión en su sentido detectivesco- minuciosa, buscando remontar el camino de los perpetradores, ordenar sus voces en el tiempo y en relación con sus actos. Ello sucedió en un contexto muy particular en el que solo una docente que no dependía de la inversión económica de un productor que evaluase los costes en términos de tiempo y trabajo podía permitirse. La promulgación de la Ley de Acceso a la Información en $2011^{11}$, corolario del establecimiento de la Comissão Nacional da Verdade (creada en 2011 e instituida el 16 de mayo de 2012) ${ }^{12}$, permitió la consulta de materiales de archivos de la dictadura, pero, aun así, las dificultades se multiplicaban. Los Acervos de la Polícia Política do Rio de Janeiro (APERJ), compuestos por unas 100.000 fotos, reunidos en 1992 (Bastos, 2009, 2010), los archivos del Superior Tribunal Militar y los del Serviço Nacional de Investigação (SNI) fueron decisivos para este trabajo. La documentación obtenida, sin embargo, todavía dispersa y fragmen$\operatorname{taria}^{13}$, había de ser tratada, cotejada y puesta en una línea de interpretación que permitiera entender su lógica (que era la del proceder represivo de los perpetradores); modo que Leandro explicó en su texto "Montagem e história. Uma arqueologia das imagens da repressão» (Leandro, 2015a) ${ }^{14}$. Es mediante este método como la autora se incorpora a estas formas - singulares, a la par que diversificadas- de pensar y hacer hablar a la imagen desde la propia imagen; un método metacomunicativo o autorreflexivo cuyo canon va de Alain Resnais a Chris Marker, de Harun Farocki a Jean-Luc Godard, de Susana de Sousa-Dias a Gabriel Périot, a pesar de las muchas diferencias que separan a estos autores. Detener o suspender una imagen fotográfica para enlazarla con series diferentes, contrastarla con la voz testimonial, utilizar disolvencias o encadenados para sugerir causalidades imprevistas; en suma, hacer de la

11 A «Lei de Acesso à Informação» fue promulgada en noviembre de 2011 (Ley Federal n 12.527/2011, http:// www.gov.br/acessoainformacao/pt-br (último acceso 19 junio 2021).

12 http://cnv.memoriasreveladas.gov.br/

13 Es posible que la fragmentación tenga un siniestro origen, al menos en parte, en la circulación de información cruzada de los servicios policíacos y militares y el hecho de que los detenidos fueran - como será el caso de nuestros tres protagonistas- transferidos de las dependencias de unos a las de otros.

14 Estudiadas con atención, estas imágenes - dice Leandro haber tenido la intuición desde el comienzo (2016: 104) - podrían revelar aspectos del dispositivo de control que las produjo. 
sucesión cinematográfica una forma de reflexión ${ }^{15}$. La disputa por las imágenes - dice Leandro (2016: 104-105) - es consecuencia del derecho de acceso a ese tipo de documentos (que fueron arrancados a sangre y fuego a los prisioneros) en el espacio sociocultural brasileño y esto - una reivindicación- lleva inexorablemente a una disputa entre las imágenes, es decir, en la mesa de montaje, porque es alli donde estas se cruzan con otras fuentes documentales y materiales del período de la dictadura para dar lugar a un discurso inteligible ${ }^{16}$. Dos cuestiones resultan irrenunciables: la materialidad del documento y el montaje como forma de hacer inteligibles las piezas de archivo a pesar y a través de sus fisuras.

Retenidos por la cámara, filmados desde una corta distancia, como si el dispositivo tratase de apropiárselos, los pequeños y deteriorados documentos recuperados conservan y aun exhiben su rugosidad, sus manchas, el irregular golpeo de impresión de una antigua máquina de escribir, el tono amarillento que la humedad ha depositado sobre un antiguo pedazo de papel. Las mencionadas fotocopias ordenadas por el encargado de seguir a su presa, los documentos que hacen inventario de lo incautado tras la operación, la trama casi ilegible de recortes fotográficos, las placas que contienen los números asignados a cada detenido: todo esto pertenece a una lógica, fue tocado por las manos -además de concebido por las mentes- de los represores y posee una enorme relevancia en aquellos momentos en los que la dictadura, desde el llamado "golpe dentro del golpe» (Acta Institucional $n^{\circ} 5$, de diciembre de 1968), profundizó en la estrategia del terror contra los enemigos y opositores y, muy verosímilmente, también en el trabajo de la «inteligencia» y vigilancia (Nercesian, 2006: 452).

Nada lo encarna mejor que la creación en julio de 1969 de la Operação Bandeirantes en Sao Paulo, centro de información e investigación que marca una etapa de coordinación entre Fuerzas Armadas y policía, entre militares y civiles, que intensificó la tortura y la represión (Machado, 2016: 152; Joffliny 2005; Risso Sales y Martins Filho, 2018: 213). Sin embargo, Antônio sostiene que, en su tortura, los victimarios llevaban sus nombres escritos sobre el uniforme, a diferencia de la práctica más secreta y camuflada instaurada tras Bandeirantes. La disparidad de fechas se debe a que Espinosa, Dora y Chael fueron capturados en Río, donde el DOI-CODI (equivalente en Río de la Operação Bandeirantes) no existía todavía. Los DOI-CODI fueron creados en enero de 1970, razón por la cual los militares de Río todavía no ostentaban nombres de guerra17.

Dos documentos particulares sobresalen del resto y ambos serán sometidos a un sutil escrutinio y tratamiento: el primero se refiere a las fotografías, pues estas no son aquí considera-

15 Estos modelos son tan diversos que van desde el film-ensayo, hasta el tratado (en el sentido en que Eisenstein fue el primero en proponer en sus notas para filmar El Capital), pero también programas políticos, sin excluir evocaciones poéticas. Su característica común sería que funcionan como imágenes en segundo grado, es decir, que el material de archivo (visual y sonoro) es analizado por medio de otras imágenes que reescriben o iluminan las primeras.

16 Ramos Monteiro (2017: 247) habla de que la apropiación de estas imágenes del poder las transforma en imágenes de resistencia.

17 Disponible en: http://www.fgv.br/cpdoc/acervo/dicionarios/verbete-tematico/destacamento-de-operacoes-einformacoes-centro-de-operacoes-e-defesa-interna-doi-codi. Última consulta: 19/06/2021. Aspecto crucial respecto a la Operaçao Bandeirantes es que su estructura tenía un estatuto anfibológico en el Estado en relación con la persecución de los llamados terroristas. Aunque no poseía un estatuto oficial, fue presentada en acto solemne en julio de 1969 por autoridades civiles y militares del estado de São Paulo, en compañía de personalidades del mundo de los negocios. No era, en suma, un departamento provisto de órganos institucionales como sí lo fue, por ejemplo, el Serviço Nacional de Informação. Este estatuto permitía que el Estado brasileño no estuviese implicado directamente en la represión más brutal que incluía tortura y asesinatos de los opositores. 
das solo en su aspecto de representación facial o corporal de una persona, sino que incorporan su componente matérico, objetual; el segundo es el documento de la autopsia de Chael, asesinado de un brutal culatazo durante una sesión de tortura.

En su condición de lo que se dio en llamar mug shots de los detenidos ${ }^{18}$, estas imágenes representan cómo las víctimas fueron vistas por los victimarios, no tanto (aunque también) por los individuos concretos cuanto sobre todo por el aparato policial que se apropiaba de sus rasgos corporales para fines prácticos, siguiendo un parámetro de fichaje nacido con el incremento del sistema de vigilancia durante la segunda mitad del s. XIX (AA.VV., 2011).

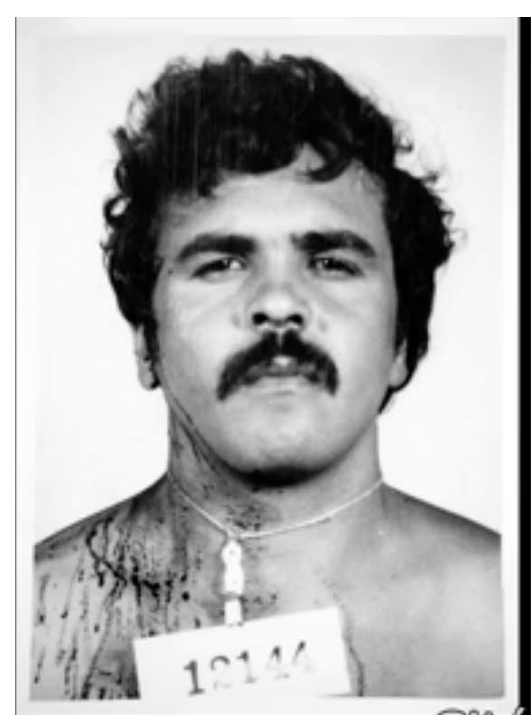

Fotograma de Retratos de identificação (Anita Leandro, 2014) reproduciendo los mug shots de los tres detenidos

De hecho, su inventor había sido el responsable del servicio fotográfico de la prefectura de París, Alphonse Bertillon, quien recurrió al término «dogmatización» para describir el método de uniformización con el que perseguía fijar la figura del malhechor (profesional y reincidente) para un reconocimiento con garantías en un período en el que la fotografía empezaba a ser aplicada a los ámbitos científicos, judiciales y administrativos. Este método pragmático, que conllevaba toma de medidas craneanas y otras cifras, frente a las de aspiraciones más científicas de Francis Galton (Sekula, 1986), posee sin embargo muy diferentes variantes, desde las practicadas en las colonias para vigilar a grupos étnicos de difícil identificación por la policía metropolitana hasta las Ilamadas fotos-trofeo, pasando por sistemas de control en regímenes democráticos ${ }^{19}$. Archivo de la represión en nuestro caso, el poder matérico de estas imágenes será puesto de relieve por Leandro en su film al exponer tanto los positivos como los negativos, tanto las fotos crudas como las marcas de numeración o anotaciones de los victimarios.

18 Véase la interesante lectura que hace Ricardo Lessa Filho (2019) desde la perspectiva de las imágenes antropométricas y la función del archivo, en una línea que va de Arlette Farge a Didi-Huberman.

19 Patrícia Machado (2016: 189) señala para nuestro caso el destinatario victimario de estas imágenes. 


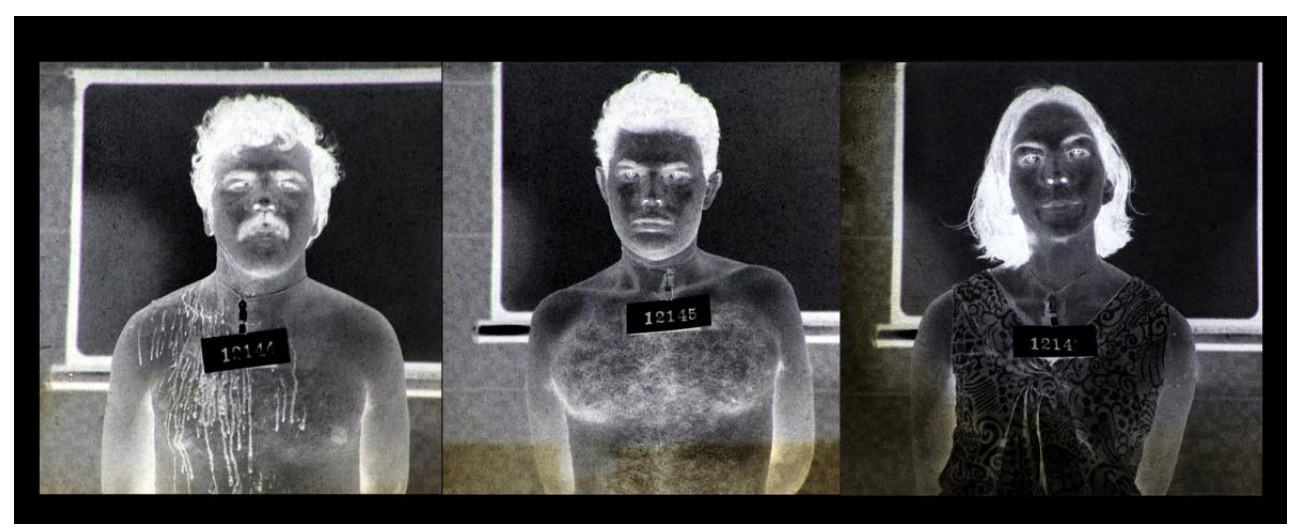

Figura 3

Fotograma de Retratos de identificação (Anita Leandro, 2014), mostrando el negativo de las fotos de detención

¿Cuáles son esas fotos, dónde se hallaron y qué uso hace el film de las mismas?

Anita Leandro describe este material en distintas comparecencias públicas, así como en publicaciones, pues la autora participó en numerosas actividades relacionadas con la difusión de los archivos de la dictadura ${ }^{20}$. Tales fuentes fotográficas son, en realidad, muy variadas: incluyen las del seguimiento, las del aeropuerto, las de los exámenes médicos en las que la muchacha -Dora - aparece desnuda, entre otras. Las fundamentales, sin embargo, son seis fotos de $6 \times 12 \mathrm{cms}$ encontradas en APERJ. El hecho de que Antônio aparezca en dos de ellas ensangrentado confirma que fueron tomadas a su llegada a DOPS, es decir, tras el enfrentamiento que se saldó con la detención. Por el contrario, sus compañeros aparecen en ellas sin marca alguna de violencia, elemento fundamental para desmontar la tesis de los victimarios de que la muerte posterior de Chael sobrevino a resultas de heridas de combate con la policía en el momento de la captura ${ }^{21}$. Los negativos, que contienen el encuadre completo, son algo más grandes: $8,7 \times 6,3$ y muestran a los dos prisioneros desnudos de cintura para arriba. Es ahí donde puede verse a Chael con lágrimas en los ojos.

\section{MATERIA FORENSE Y PUESTA EN ESCENA DE LA MUERTE}

Los tres detenidos fueron torturados en la DOPS de Guanabara y trasladados a Vila Militar de Río de Janeiro, donde la tortura prosiguió. En el curso de esta, al día siguiente, Chael fue golpeado con un fusil en el pecho $y$, aunque siguió siendo electrocutado, el culatazo produjo un efecto letal a las pocas horas, como refiere Antônio. Leandro coloca entonces el negativo de la foto de Chael y, lentamente, va disolviendo esa imagen hasta el negro completo, metáfora anticipada de la muerte del joven.

20 Véase, por ejemplo, los debates celebrados en el marco de la exposición Arquivos da ditatura, que se extendería entre el 5 y el 21 de 2014.

21 Leandro compareció ante la CNV presentando estas fotografías por su importancia pericial cuando su documental estaba todavía en curso. http://cnv.memoriasreveladas.gov.br/outros-destaques/423-fotos-exibidas-em-audiencia-da-cnv-desmontam-versao-do-exercito-para-morte-de-estudante.html. Última consulta: 19/06/2021. 

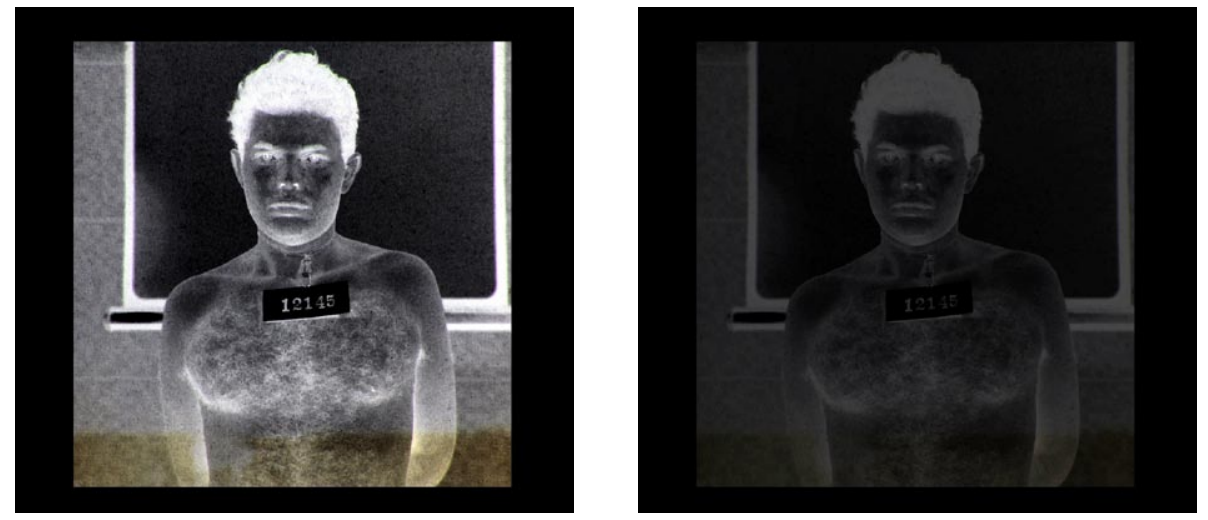

Figuras 4 y 5

Fotogramas de Retratos de identificação (Anita Leandro, 2014) disolviendo en negro la figura de Chael

Cuando volvemos a oír la voz de Antônio, la pantalla continúa en negro: «los gritos de Chael cesaron. No volví a oír la voz de María Auxiliadora». De repente, como una aparición, surge ante nosotros un documento sellado con el membrete del Servicio Médico-Legal del Hospital Central del Ejército. Es la página inicial de la autopsia de Chael Charles Schreier, fechada el veinticuatro de noviembre de 1969 (recuérdese que la detención tuvo lugar en la tarde del 21 y la muerte el 22) y fue firmada al día siguiente, en Rio de Janeiro, por el doctor Oswaldo Caymmi Ferreira, jefe del servicio.

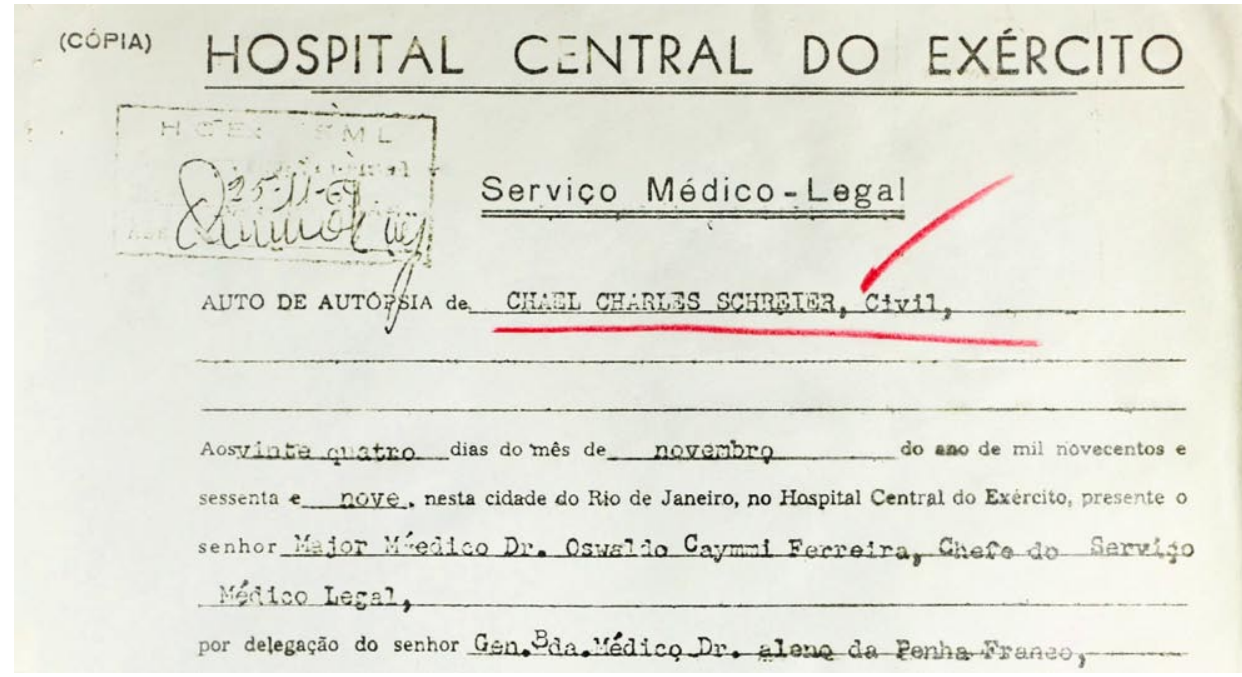

Figura 6

Fotograma de Retratos de identificação (Anita Leandro, 2014) mostrando la primera página de la autopsia realizada a Chael por el servicio forense del Hospital Central del Ejército

A lo largo del extenso fragmento que sigue, la imagen permanece fija sobre este encabezamiento. Sin embargo, una voz en off lee el documento oficial, que arranca con la identificación del sujeto autopsiado, la de su familia, la descripción de su físico y el estado de conservación del cadáver que había sido remitido para la práctica de ese informe. Ese documento, disponible en- 
tre la documentación, es deliberadamente hurtado a nuestros ojos para que nos alcance a través de la voz del que fue su camarada ${ }^{22}$. Se trata de una descripción pormenorizada del estado del cadáver tal y como fue analizado científicamente: con una terminología fría y rigurosamente anatómica que la voz de Antônio, ubicado fuera del alcance de nuestra mirada, recita como si se la apropiase, a pesar de que los tecnicismos del lenguaje le habian de ser completamente extraños ${ }^{23}$. El relato tiene una fuerza demoledora, pues constituye un complejo ejemplo de apropiación de un documento que, este sí, escapó a las previsiones y al control de los perpetradores. Vehiculado por una enunciación diferente a la que lo emitió, este "testimonio involuntario» es una fuga del aparato de represión y sus ramificaciones de complicidad. Es entregado al camarada Espinosa por la directora para que este, desde su presente de 2013, más de cuarenta años después de la muerte de Chael, nos lo transmita a nosotros. Es así como nos alcanzarán los efectos dejados por los torturadores sobre el cuerpo de ese estudiante de quinto curso de Medicina: un estímulo terrible para reconstruir la violencia y el dolor que Chael debió sufrir. Dicho en otras palabras, Antônio, mediante la lectura del documento, no está solo relatando las causas de una muerte, sino haciéndonos imaginar las acciones del verdugo que la provocaron; lo hace, pues, en clave metonímica, es decir, a partir de sus efectos. Su reproducción nos parece imprescindible:

Inspección externa. El cadáver es el de un hombre blanco, que mide 1,73 m, con buena complexión física, en buen estado de conservación. Semi-rigidez muscular generalizada. En el pabellón auricular izquierdo, se encuentra una mancha azulada que, tras una incisión, revela una infiltración hemorrágica subyacente. Dientes regularmente conservados. Los párpados están cerrados y presentan manchas rojoazuladas que, tras una incisión, revelan una infiltración hemorrágica. Barba y bigote sin afeitar. Ojos castaños-verdes. Pupilas dilatadas. Herida en el mentón con cinco puntos de sutura en hilo de seda ${ }^{24}$. En el examen del tórax y abdomen se encuentran manchas rosadas y escoriaciones marrón oscuro, que recuerdan la forma de un tres irregular. Las formas citadas, tras incisión, revelan infiltración hemorrágica.

Inspección interna. Cavidad torácico-abdominal. A la abertura de la cavidad peritoneal, se observa que hay sangre en estado líquido en gran cantidad. Se encuentran fracturas con infiltración hemorrágica en la unión de la tercera, cuarta, quinta y séptima costillas derechas y fractura de la segunda, tercera, cuarta, quinta, sexta, séptima y octava costillas izquierdas con infiltración hemorrágica. El corazón, en tamaño y consistencia normales, y el examen de cortes no muestra alteraciones. En el abdomen se percibe sangre líquida en gran cantidad. Causa del fallecimiento con la necropsia finalizada: contusión abdominal, con fracturas del mesocolon transverso y del mesenterio con infiltración hemorrágica.

En el curso de la lectura, el plano corto de Chael comienza a superponerse al documento y poco a poco desplaza a este para hacerse enteramente visible en el instante en que Antônio ha concluido la lectura. La pantalla muestra el número de la ficha a la que se refiere el caso. Sucede como si, al tiempo que nos recorre el escalofrío por el dolor que hubo de sufrir el joven, su imagen resurgiese cual epifanía para, tras breve mirada, desaparecer convertido en un caso archivado. La sutileza de la secuencia es sorprendente: la mirada de Chael a cámara se ancla en la que un día dedicó a aquellos que lo iban a fichar, torturar y asesinar. Ahora, en

22 Véase la página web de la Comissão Nacional da Verdade: https://www.slideshare.net/comissaonacionaldaverdade/apresentao-sobre-a-morte-de-chael. Última consulta: 14/04/2021.

23 Antônio tuvo que ensayar esta lectura, como me recuerda Leandro, hasta tal punto el lenguaje le era ajeno y casi impronunciable.

24 Esto revela la complicidad de médicos, pues demuestra que hubo asistencia médica durante la tortura. 
cambio, nos apunta fijamente a nosotros para que podamos compartir su imagen todavía intacta, antes de ser golpeado fatalmente cuando, en realidad, se está relatando su muerte como pasada. Más que una muerte inminente, nos encontramos ante una muerte latente, que intoxica por completo la atmósfera. Gracias a un recurso del montaje, la mirada de los perpetradores del crimen, a pesar de permanecer inscrita en la fotografía, asume un papel diferente: emerge desde el interior del documento que certifica la muerte para convertirse en una acusación sin paliativos contra quienes la provocaron. La mirada de Chael actúa como una denuncia y, aunque no puede hacerlo sino desde la celda en que lo confinaron sus verdugos, la confluencia de la voz de su camarada Antônio le devuelve la compañía en la que murió a través del documento que impidió el engaño (a saber, la autopsia). La imagen, limpia de marcas de violencia, y la autopsia, repleta de consecuencias de la tortura, colisionan, no para devolver a la vida al muchacho (esto resulta imposible), pero sí al menos para refutar categóricamente el relato de sus verdugos, pues atestigua que Chael no fue herido en combate, como pretendió el capitán Celso Lauria al firmar un documento tres meses más tarde (el 27 de febrero de 1970) que exculparía a sus asesinos, sino que llegó ileso a las dependencias de la policía para ser asesinado después.

En suma, nos hallamos ante una pieza performativa de represión - la foto de perpetradorrecortada hasta convertirse en un primer plano que nos interpela-, un documento de época que desmiente el relato de los victimarios; una voz - la de Antônio- que no habla en su nombre, sino que se apropia, por voluntad de la cineasta, de esa denuncia. Un efecto de cierre archivistico del caso concluye la secuencia, como si fuese la tapa de un féretro llamada a guardar su secreto para siempre, pero que ha fracasado en el intento.
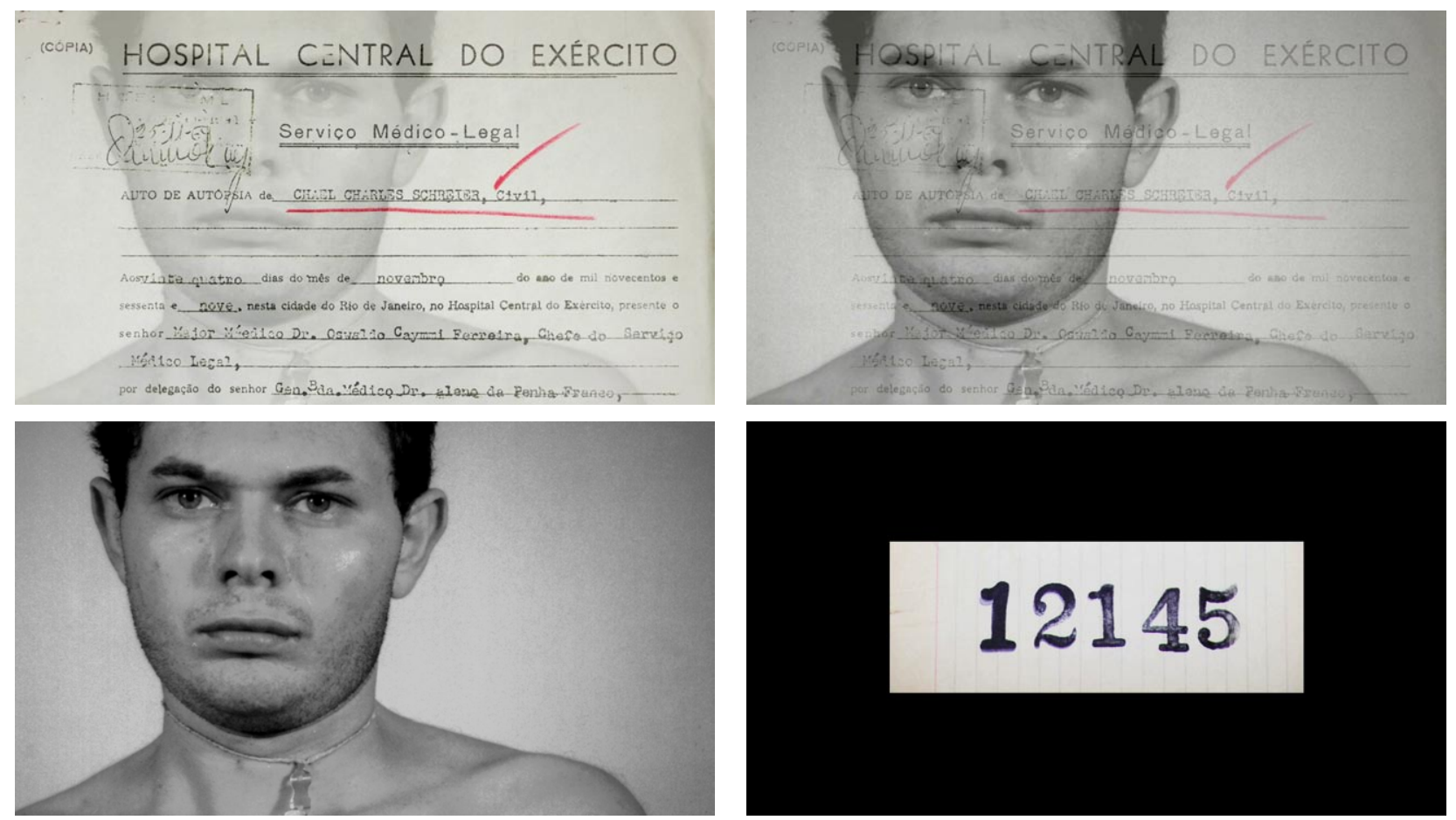

Figuras 7 a 10

Fotogramas de Retratos de identificação (Anita Leandro, 2014) en los que la foto de Chael se superpone al texto de la autopsia hasta hacerlo desaparecer y concluir con un plano con el número de expediente 
Fue precisamente el conocimiento de este documento de la autopsia, seguido de una segunda encargada por la familia de Chael tras la entrega de su cuerpo por la policía para el ceremonial funerario judio que le siguió, lo que desencadenaría el primer gran escándalo a escala nacional e internacional sobre la práctica de la tortura en Brasil. La revista Veja, en su número 66 (10 de diciembre de 1969), dio la señal de alarma y nada menos que el New York Times publicaba el 3 de diciembre de 1969 un artículo titulado «Ex-Student Dies After Rio Arrest; Charges of Police Torture Increasing in Brazil», firmado por Joseph Novitzki. Al tiempo que la prensa nacional seguía dando a conocer el caso, Le monde y The Times, entre otros, prosiguieron la estela de denuncias en el mundo.

\section{EL CONTRAPUNTO TESTIMONIAL: OTRA VIDA, OTRA MUERTE}

Como hemos podido comprobar en el caso anterior, las imágenes de perpetrador que sirven de soporte a este caso se encuentran en el film de Anita Leandro contrapunteadas por una batería de enunciaciones. La primera de estas voces procede de las entrevistas recuperadas a través de dos materiales de archivo: el citado documental No es hora de llorar y otro complementario, de cuño también militante, realizado por los norteamericanos Haskell Wexler y Saul Landau en las mismas fechas. Los estadounidenses habian desembarcado en Chile poco antes de la llegada del contingente de liberados brasileños con el fin de entrevistar al presidente Salvador Allende. El film llevaría por título Brazil: A Report on Torture y vería la luz en 1971. Ambos films recogían los testimonios en caliente de los antiguos detenidos y torturados, quienes se mostraron dispuestos a colaborar no solo con sus relatos ante la cámara, sino también mediante una reconstrucción de los métodos de tortura sufridos; escenificaciones que exhibian instrumentos de tortura o sucedáneos explicando su uso, a la vez que colocaban los cuerpos en las posiciones de suplicio; todo ello con el fin de documentar actos que se habian sustraído a las cámaras. Este metraje resultaba a todas luces pionero para espectadores desconocedores de métodos como pau de arara (una barra metálica en la que se enrollaba al prisionero y que causaba grandes dolores articulares, teniendo la ventaja de no dejar señales ${ }^{25}$ ), las electrificaciones, los estrangulamientos y asfixias, en tiempos anteriores a su uso en el Chile pinochetista o la Argentina de Videla, entre otros lugares ${ }^{26}$. Con todo, Leandro recoge de estos dos documentales aquello que le garantiza una continuidad con uno de los personajes de su relato: Dora. Es la historia de su detención contada por ella misma en ambas películas (en blanco y negro la primera, en color la segunda) lo que hace posible su encarnación del itinerario del exilio, mediante su acogida en Chile. El resto del film de Leandro girará en torno al curso posterior de su biografía, en cierto modo representativa de muchos otros exiliados que habrian de abandonar precipitadamente Chile tras el golpe militar del 11 de septiembre de 1973.

El segundo de los recursos será la incorporación de otro testigo convocado por la directora: Reinaldo Guarany Simões, un personaje incluido en la misma lista de liberados que volaron a

25 El caso del pau de arara tenía una función adicional para los torturadores: dejaba el cuerpo de la víctima suspendido, es decir, «libre» para poder ser expuesto a todo tipo de torturas posteriores (caídas, puñetazos, descargas eléctricas, etc.). Estos cuerpos desnudos quedaban, así, a merced total de los victimarios.

26 Esta forma de re-enactment por parte de los mismos torturados ante las cámaras, realizada por voluntad testimonial, pero a gran coste emocional y traumático - como indican varios de ellos-, constituye un caso pionero en el ámbito del género documental. 
Santiago de Chile y que, más tarde, exiliado en Alemania, se convertirá en su compañero sentimental hasta el mismo día de la muerte de la muchacha. Complementario del primer testimonio en la medida en que cubre un período posterior de su vida (Antônio permaneció en la cárcel en São Paulo hasta 1973) y refiriendo lo acontecido con posterioridad a su liberación, no es menos cierto que Leandro afrontaba dos testimonios y dos personalidades muy diferentes: Antônio se expresaba, incluso muchos años más tarde, con el tono y la solidez ideológica del comandante revolucionario que había sido, aunque Leandro logró atenuar en el montaje este aspecto privilegiando el relato de su experiencia ${ }^{27}$. La sensibilidad y la experiencia de Reinaldo eran muy distintas: su militancia en Ação Libertadora Nacional (ALN) ${ }^{28}$, se combinaba con su sensibilidad artística (su condición de escritor y pintor), además de haber convivido con Dora en un momento muy diferente y de estar atravesado por el dolor de su pérdida. La disparidad de estos dos personajes amenazaba con debilitar la coherencia estructural de un documental que había partido del discurso y las imágenes de perpetradores y que se organizaba en torno a los retratos de identificación.

De ahí que la directora buscase un parámetro común para filmar ambas entrevistas conservando el control de las mismas en lugar de dejarse en cada caso arrastrar por la personalidad de cada uno de los testigos. Esto no era sencillo, pues había que excluir imponer a los personajes algo externo a su personalidad. Reinaldo fue filmado por la cineasta, al igual que Antônio, en una sola jornada (el domingo 7 de septiembre 2013), es decir ya casi al final del tiempo de investigación documenta| ${ }^{29}$. El dispositivo de rodaje es también muy similar en su sobriedad: un fondo blanco desnudo y un plano medio con renuncia a efectos como primeros planos, insertos o el uso del zoom; una óptica de $50 \mathrm{~mm}$ y, en lo que a la forma de la entrevista se refiere, un desarrollo estructurado, pero no impuesto, que permite a la directora conservar las riendas del encadenamiento entre temas. Lo hizo Leandro mediante la mostración de fotografías sucesivas, en orden cronológico, que ella había ido obteniendo durante su período de investigación y que habian de actuar como memory triggers (disparaderos de memoria) $)^{30}$. Tanto es así que Antônio muestra su sorpresa ante la fotografía en la que aparece ensangrentado, pues no la había visto jamás. La directora evitó mostrar a Reinaldo fotos de Dora ${ }^{31}$.

El relato de Reinaldo se inicia con la reunión, en el aeropuerto de Galeão, de los guerrilleros escogidos para el canje con el embajador suizo, los cuales proceden de lugares bien distintos de Brasil (Dora, por ejemplo, venía de Minas Gerais). En paralelo a la identificación en las fotografías de muchos de los que saldrán del país, Leandro introduce elementos que permiten

27 Entrevista citada.

28 La Ação Libertadora Nacional fue formada por los disidentes del Partido Comunista Carlos Marighella, Joaquim Câmara Ferreira y Virgílio Gomes da Silva (http://www.fgv.br/cpdoc/acervo/dicionarios/verbete-tematico/ acao-libertadora-nacional-aln. Última consulta: 11/06/2021.

29 El dato es relevante para comprender la modestia de la producción que contrasta con el tiempo invertido por la cineasta-investigadora rebuscando archivos y documentándose para su obra. La condición de historiadora que asume la cineasta reafirma esa tendencia mencionada a pensar la historia a través de las imágenes y utilizar las imágenes como forma de pensamiento, según mencionábamos en una nota precedente.

30 Los «memory triggers» son recursos utilizados por la historia oral o la historia con fuentes orales como instrumentos (objetos, fotografías, palabras incluso) que contribuyen a sumergir al informante o entrevistado en el pasado, levantando ciertas censuras y contribuyendo a la activación de la palabra. Véase una reflexión de conjunto de su función en relación otros recursos retóricos en la obra de una de las más profundas pensadoras de fuentes orales en relación con la historia, en Passerini (2018).

31 Según nos refiere la directora, el asunto del suicidio de Dora solo fue evocado a las $17 \mathrm{~h}$ de la tarde de una sesión de rodaje que había comenzado a las $9 \mathrm{~h}$. 
ofrecer datos sobre este estudiante de psicología que nos guiará durante la última parte de su documental. Así, mientras su voz discurre, la cámara cinematográfica se apoya en las fotos del aeropuerto previamente a la partida, algunas muy deterioradas $y$, pese a todo, preciosas; las penetra y aísla detalles, marca algunos nombres identificativos. Esas mismas fotos le han sido entregadas a Reinaldo y nosotros las vemos a pantalla completa. Su lectura atenta permite reconstruir detalles significativos: la custodia de policías hasta Santiago de Chile, los gestos de censura hacia los puños en alto con que saludaban orgullosos los ex prisioneros. Reinaldo es recogido aqui ciertamente por el valor de su testimonio personal, pero es fundamental su condición de nexo con los últimos años de la vida de Dora. Su paso por la prisión, su encadenamiento y tortura, las acusaciones que pesaban sobre él, sus fotos de identificación en la documentación policial: todo ello contribuye a perfilar otra silueta de combatiente y otra modalidad de la memoria. Entonces irrumpen unas fotos posteriores a los episodios de la tortura que muestran a la muchacha en el estudio de foto de la policía; fotos tomadas en el momento de la salida de los prisioneros durante los exámenes médicos ("exames de corpo de delito»). Estas fueron filmadas con pudor por Leandro evitando la desnudez obscena con la que sus victimarios la habian humillado.

Por fin, después de varios días de espera en el aeropuerto, la comitiva llegó a Santiago y los militantes de la guerrilla urbana brasileña mostraron su escaso entusiasmo, cuando no desafección, por el gobierno de Allende. Acto seguido, el golpe de Estado de Pinochet y la amenaza sobre estos extranjeros considerados terroristas llevó a la búsqueda de asilo en la embajada de México, luego Bélgica, Francia y, por fin, la llegada a Alemania donde serían considerados "heimatlos» (apátridas). Es entonces $-y$ no olvidemos que hay una elipsis de tres años-cuando irrumpe el dolor; un dolor de signo distinto (más íntimo) que llevó a Reinaldo a desembarazarse de las imágenes y los objetos de Dora después de su muerte, pues la herida se hacía imposible de curar.

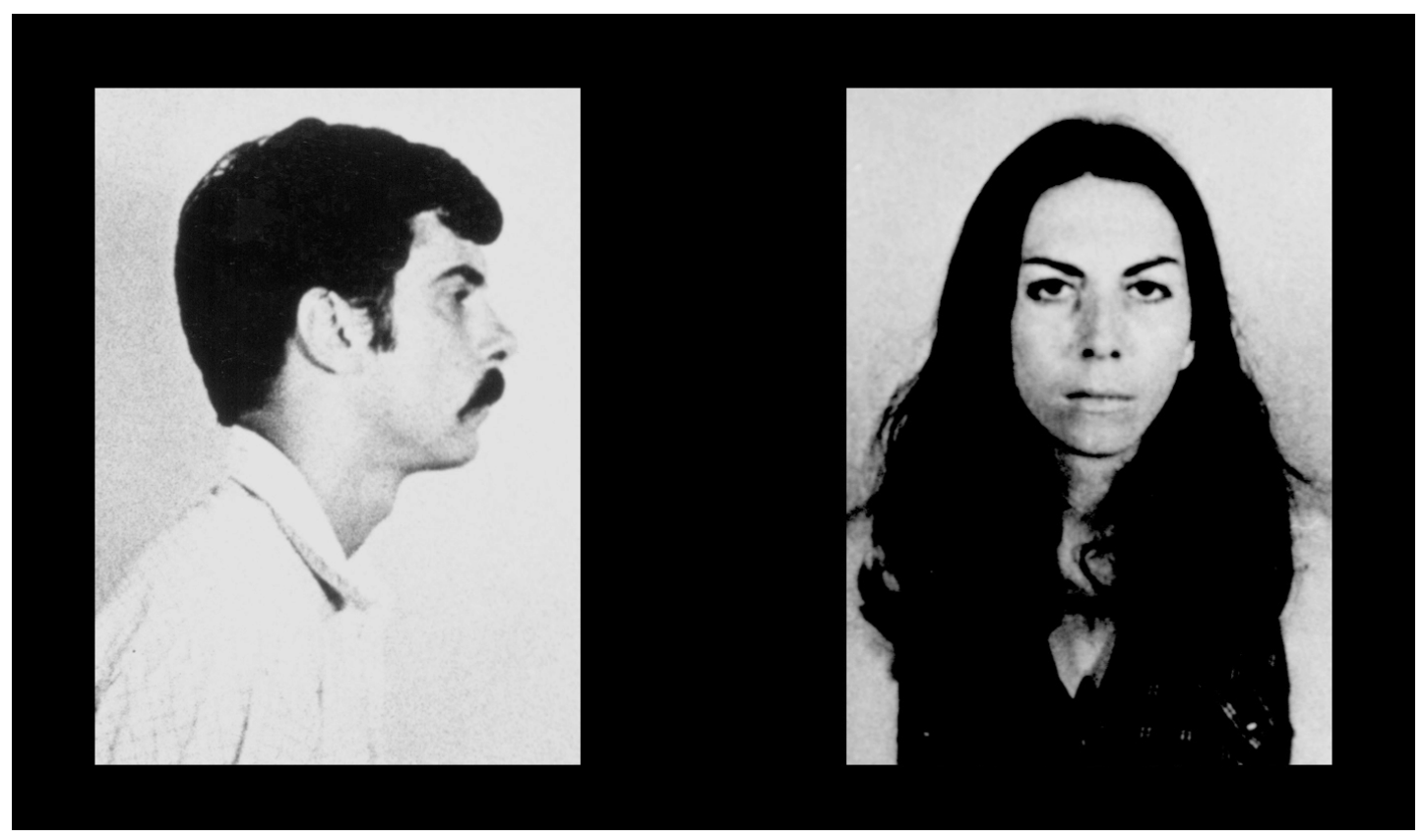

Figura 11

Fotograma de Retratos de identificação (Anita Leandro, 2014) con fotos alternativas de Reynaldo y María Auxiliadora 
La pantalla reproduce dos imágenes: una de frente a la derecha, la de Dora, otra de perfil, la de Reinaldo. Estas fotos fueron tomadas por la policía brasileña entre diciembre de 1969 y enero de 1970, en el momento de su partida. Formaron parte del Álbum dos Banidos, publicado por los militares con motivo de cada canje de prisioneros por diplomáticos capturados por la guerrilla. Ya en Alemania, esa muchacha, que aprendió con rapidez y destreza la lengua alemana y obtenía óptimos resultados académicos, sufrió un trastorno repentino, un brote psicótico. Las razones permanecen oscuras: quizá secuelas de su condición de torturada, pues como dejó escrito Jean Améry: «quien ha sido sometido a la tortura es incapaz de reconocerse ya en el mundo», ya que "[e]l ultraje de la aniquilación es indeleble» (1995: 79). La idea es difícil de rechazar, pero la evidencia falta. Reinaldo, por otra parte, guarda celosamente por decoro - él mismo lo dice - secretos que acompañan a los últimos compases de la vida de Dora que sería obsceno desvelar.

Las imágenes anteriores de identificación hacen despegar el relato de nuevo, mas ahora ambos personajes están tomados de perfil, como si la realizadora estuviese cercando el nudo impenetrable que preservase su misterio. Terapias de grupo, estudios en la universidad, salidas periódicas de los dos compañeros ${ }^{32}$, una cotidianeidad que Reinaldo lleva a un lugar y tiempo precisos, lindando ya con el instante fatal. Este se encuentra en la propuesta que uno de aquellos días hizo a Dora de emigrar a algún cálido lugar del planeta, quizás a alguna de esas antiguas colonias portuguesas de África que habian logrado la independencia recientemente, como Angola o Mozambique. Es un momento crítico: lo es por la aproximación a ese punto de giro en que todo pudo ser corregido (salvado). Es como si la esperanza de una salida a esta tenaza del pasado que retorna hubiese surgido ante Reinaldo mientras él se zambullía en el recuerdo; como si la palabra, mientras reproducía las que un día dijo a Dora en la intimidad, hubiesen hecho renacer en él el espejismo retrospectivo de que la huida que no fue volvía a ser posible, que disponía de una segunda oportunidad. Demasiado dolor conlleva esta nueva desilusión, pues actualiza la imposibilidad de haber doblegado el destino aciago. En ese punto, Reinaldo no lleva puestas las lentes que utilizaba para observar las fotografías; se mesa la barbilla mientras guarda en su regazo las fotos que le han ayudado a evocar aquellos años de Berlín. Ahora ya no necesita observarlas, pues el pasado lo desborda desde dentro. Cabecea en señal de fatalidad y las palabras ya no vendrán en su auxilio. Se levanta y abandona la escena. La cámara se encuentra tan cerca que Reinaldo casi la roza al salir. La cámara de Leandro permanece impasible: no corta ni la imagen ni suspende la captación del sonido, pues la escena - esa es la valerosa apuesta- continúa en los aledaños del campo visual, si bien Leandro no se permite pivotar esa cámara en dirección a quien ha decidido suspender su presencia, pues de hacerlo quebraría el respeto que debe a su personaje, instrumentalizándolo. Ese campo vacío deslumbrantemente blanco es parte del relato, de la confrontación del presente con aquel pasado que retorna para hacerse insoportable. Porque filmar un testimonio es filmar también el instante en que la linealidad de un discurso se resquebraja, donde el silencio - esa forma vacía y a la vez saturada de lenguaje - impone su reinado. Estrellados contra esa superficie blanca, impoluta, el campo vacío no solo da forma a la muerte antes de que Reinaldo la pronuncie; habla también de su desolación sin remedio.

32 Y algo que no se dice: el estrecho cordón policial que obligaba a Dora a presentarse a diario ante las autoridades para estar ubicada y localizable, dado su estatuto de apátrida. 


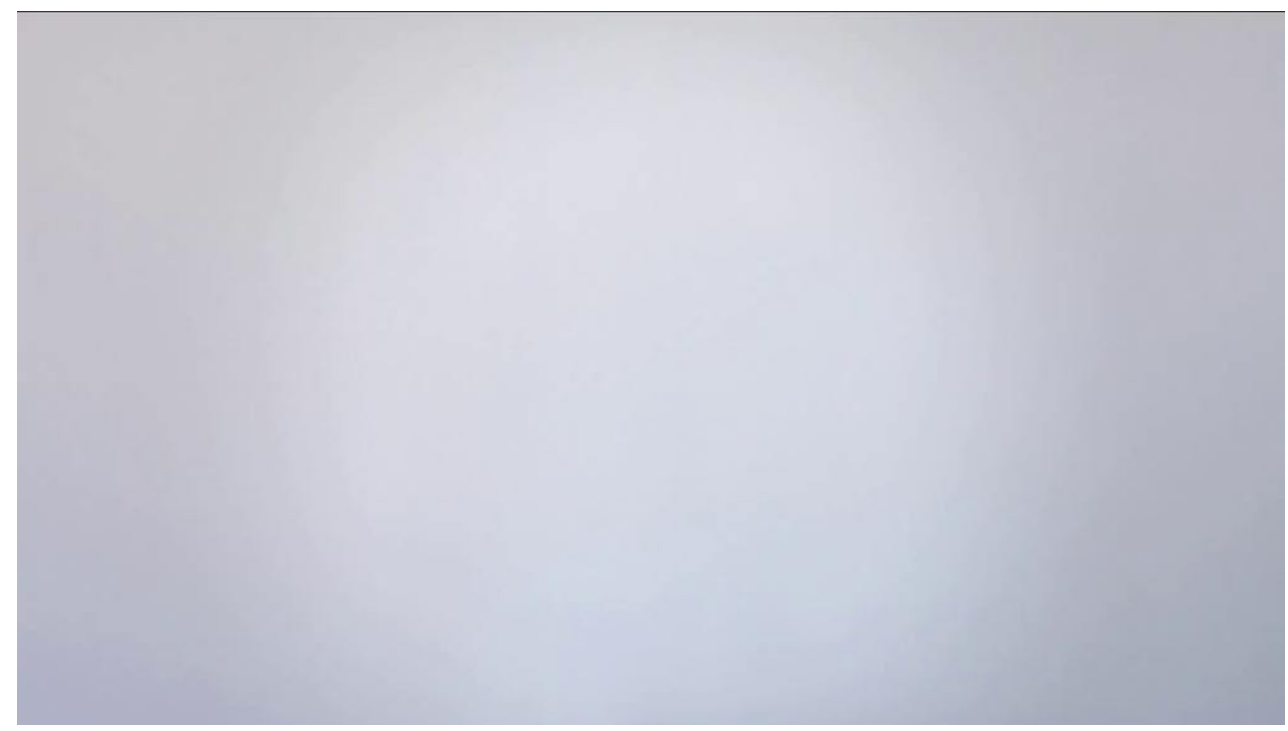

Figura 12

Fotograma de Retratos de identificação (Anita Leandro, 2014) representando el campo vacío que encarna la ausencia y la desaparición

Reinaldo se ha repuesto mientras permanecía fuera del alcance de nuestra mirada. Retorna al lugar del testimonio, aunque ya estaba en él sin saberlo; disculpándose, recompone el gesto y confiesa la culpa que le atenaza: fue un error por su parte no pedir ayuda a alguien; en suma, debió presentir la amenaza. Sus ojos están enrojecidos, su nariz licuada revela que se escaparon algunas lágrimas, contenidas, pero su discurso conserva una apariencia de normalidad. Algo, sin embargo, acelera su dicción, su gestualidad parece rígida, como si hubiese perdido entretanto esa compostura que le caracterizaba hasta entonces, esa bien escandida sintaxis del recuerdo. Su descripción del último día tiene la sequedad de la crónica: Dora tenía previsto ir a la terapia de grupo, cenar con sus compañeros de la universidad. Bajó al metro - dice Reinaldo- y se arrojó al primer tren. Un testigo la vio. La pantalla corta a negro. Un cartel escueto expone: «Dora y Reinaldo vivieron juntos en el exilio desde el comienzo de 1971 hasta el suicidio de ella el primero de junio de 1976». Nuevo cartel: "Después del suicidio de Dora, el gobierno alemán dio asilo político a todos los brasileños en situación ilegal». Otro: «Reinaldo Guarany rechazó la oferta tardía de los alemanes y se refugió en Suecia hasta 1980, cuando regresó a Brasil».

Ese instante de la evocación del suicidio de María Auxiliadora constituye la clausura del film: fue su voz lo primero humano que oímos en el film; su imagen, bajo los ojos del sabueso que la perseguía, lo primero que vimos. Es ella sin duda el hilo conductor del film ${ }^{33}$. Ahora sabemos

33 Dora fue y continúa siendo un personaje de gran resonancia en el universo brasileño que evocó la dictadura a mediados de la segunda década del siglo actual. En 1978, Luiz Alberto Sanz, el mismo autor que la filmó en 1970, realizó Quando chega o momento (Dora) en Suecia en colaboración con Lars Säfström, pero rodando en Berlín, Bochum, Colonia y París. En ese film Reinaldo intervino como co-guionista (Leandro, 2015b: 315 y ss.). El Memorial da Resistência de Sao Paulo y el Núcleo Memória produjeron en 2014 (A)DOR(A), una representación con texto de Pedro Guilherme y dirección de Henrique Stroeter y Guilherme de 75 minutos de duración inspirada en la vida de María Auxiliadora Lara Barcellos. En una atmósfera experimental y surreal, Lara era encarnada por tres actrices, cada una de las cuales daba forma a su condición de mujer, guerrillera y torturada. Más obras sobre Dôra son el film Alma clandestina, realizada por el portugués José Barahona, así como el espectáculo de teatro De Dôra, de la actriz Sara Antunes (2021). Estas dos últimas utilizan las imágenes de la policía. 
que esa aparición en la que la muchacha refería su detención era, en realidad, una epifanía y si el film cerraba su primera parte con una muerte -la de Chael-, concluye su segunda mitad con la desaparición de aquella que logró salvarse en noviembre de 1969, pero arrastró el estigma como una suerte de condena fatal que acabaría con su vida casi siete años más tarde.

El film se cierra con la enumeración de los cuatro nombres de sus protagonistas, con sus años de nacimiento y de su muerte. La disposición es harto curiosa: el marco lo ofrecen los dos testigos supervivientes - Antônio y Reinaldo-, ubicados en la capa del tiempo más cercana, 2013; entre ellos, yacen las dos víctimas: Chael, muerto bajo tortura el 22 de noviembre de 1969, Dora, fallecida tal vez a consecuencia de su experiencia de tortura y exilio en Berlín en 1976.

\section{CONCLUSIONES: MATERIALES DE PERPETRADORES}

El film analizado en este texto, haciendo un uso pormenorizado - creativo a la vez que científicamente riguroso- de materiales de archivo muy diversos, así como de testimonios (cercanos a los hechos y también retrospectivos y muy alejados en el tiempo), atribuye un papel decisivo a los instrumentos puestos en marcha por los agentes de la represión, los torturadores, sus servicios administrativos, las conexiones entre policía y Ejército, las correspondencias (que aquí fallan en un inesperado punto) con un dispositivo criminal de medicina legal (representado en el informe forense). Todo ello permite insertar esta perspectiva de estudio en ese ambiguo, pero no menos reconocible, giro hacia el estudio de los perpetradores. Permítasenos un breve excurso antes de concluir.

En los últimos años, el estudio de los perpetradores de violencia de masas ha crecido en publicaciones académicas, pero sobre todo ha ganado espacio en secciones de museos, exposiciones, memorias y biografías, medios de comunicación y, como nuestro caso demuestra, también en manos de cineastas y artistas, que se han interesado por sus artefactos, órdenes, documentos, imágenes y dispositivo criminal de conjunto. Si durante muchos años este ámbito de estudio vivió dependiente de la Shoah, considerada el modelo de toda violencia de masas, esta situación ha cambiado en las últimas décadas. Ciertamente, el exterminio judio a manos del Tercer Reich y sus aliados produjo documentación ingente y ha ensayado el mayor rigor metodológico y competencia académica que podamos pensar, hasta haber generado una rama específica conocida como Holocaust Studies. Sin embargo, el sometimiento - sobre todo implícito- a este modelo o, si así se prefiere, el peso de su alargada sombra se convirtió en un corsé que limitaba perspectivas y minimizaba singularidades de otros genocidios o violencias de masas, como Ruanda, el Gulag o el genocidio camboyano, entre otros. Los casos de América Latina (y no solo del Cono Sur) presentaban, en cualquier caso y decididamente, una casuística inaprehensible con los únicos instrumentos de los Holocaust Studies.

Con todo, lo más relevante es que el estudio del dispositivo de destrucción y de las personalidades que lo llevaron a cabo ha ampliado hoy sus horizontes para abordar los productos, los objetos y las representaciones de los que se sirvieron los victimarios. Estos horizontes enriquecen el estudio, pero al mismo tiempo obligan a introducir nuevos criterios analíticos. Un objeto muy particular entre todos ellos es el fotográfico, pues se ubica a medio camino entre la idea de representación (capta y da a ver rostros, cuerpos y la expresión de sentimientos) y la materialidad de su textura objetual (puede tocarse, positivarse, ampliarse, circular entre las 
gentes, usarse como reliquia, disponerse en el recorrido de un museo). Las fotografías de represión -en tanto en cuanto imágenes de perpetrador - se han convertido en un objeto muy especial de estudio porque, siendo producto de la mirada de los victimarios y de su dispositivo de destrucción, contienen y ofrecen a la visión la imagen de la víctima y permiten, por tanto, una recuperación simbólica por medio de la reapropiación. Baste citar los documentales 48 (Susana de Sousa-Dias, 2010) y S-21. La máquina de matar jemer roja (Rithy Panh, 2003) para recordarlo. Mas también se manifiesta en los museos: de Auschwitz a Sighet (Rumanía), de las fotos de los detenidos por sorpresa en los procesos del Terror en Moscú (1937) al museo del Aljube en Lisboa, entre tantos otros, los muros de rostros han dado lugar a obras a su vez de artistas y dramaturgos, a partir de un trabajo con tamaños, luces, voces y colores llamados a redimir su recuerdo. Su exportación a páginas web era cuestión de tiempo.

En esta problemática de tratamiento y reapropiación se mueve Retratos de identificação (Anita Leandro, 2014), un film que utiliza la forma fílmica - la composición, el montajecomo instrumento para pensar su materia y dar forma a la investigación histórica. En tal empresa no participan solo las fotografías; también lo hacen los informes, los archivos, en su condición de objetos que envejecen y se deterioran, pero también estos pueden cobrar una segunda vida. Es necesario poner en diálogo esos objetos del pasado impregnados de la mirada de los victimarios con otras capas temporales que los iluminen retrospectivamente. $R e-$ tratos de identificação es, en este sentido, un film minimalista por su depuración: dos entrevistas realizadas por la directora en tan solo dos jornadas de rodaje, dos films militantes de principios de los años setenta, entran en colisión con el material de perpetradores. El montaje hará el resto. En un cine que se esfuerza por descifrar la realidad histórica, una gran cantidad de discursos corren parejos al del film, el más importante de los cuales quizá sea el de la Comissão Nacional da Verdade y sus consecuencias políticas, sociales y culturales ${ }^{34}$. En esta vía intermediática, las imágenes de la aflicción, impregnadas de la iniquidad de su origen, no pueden exponerse sin ser intervenidas, interceptadas, y tal vez redimidas, porque solo así puede salvarse - deficiente salvación, no cabe duda- a los seres cuya imagen contienen. Imágenes, inexorablemente, del dolor.

\section{BIBLIOGRAFÍA}

AA.VV. (2011). Fichés? Photographie e identification 1850-960. París: Perrin.

Améry, J. (1995[1966]). Par-delà le crime et le châtiment. Essai pour surmonter l'insurmontable. Arles: Actes Sud.

Bastos, M.T.F. (2009). Fotografia e Comunismo: imagens da Polícia Política no Arquivo Público do Estado do Rio de Janeiro. ANPUH - XXV Simpósio nacional de história. Fortaleza.

Bastos, M.T.F. (2010). Imagens secretas: fotografias da Polícia Política no acervo do Arquivo Público do Estado do Rio de Janeiro. Revista do arquivo geral da cidade do Rio de Janeiro, 4, 31-49.

34 Véase, por ejemplo, la audiencia pública de la CNV sobre la tortura y muerte en Vila Militar, con la declaración de Antônio Espinosa el 24 de enero de 2014. https://www.slideshare.net/comissaonacionaldaverdade/apresentao-sobre-a-morte-de-chael. Última consulta: 30/06/2021. 
Costa Pereira, L.L. (2014). Nos arquivos da polícia política. Reflexiões sobre uma experiencia de pesquisa no DOPS do Rio de Janeiro. Acervo, Rio de Janeiro, 27(1), 254-267.

Hirsch, M. (2001). Surviving Images: Holocaust Photographs and the Work of Postmemory. The Yale Journal of Criticism, 14(1), 5-37.

Leandro, A. (2015a). Montagem e História: una arqueologia das imagens da repressão. En A. Brandão y R.L. De Sousa (Eds.), A sobrevivência das imagens (pp. 103-119). Campinas: Papirus.

Leandro, A. (2015b). Cinema do exílio. Entrevista com Luiz Alberto Sanz e Lars Säfström. Aniki, 2(2), 349-359.

Leandro, A. (2016). Os acervos da ditadura na mesa de montagem. Logos 45, 23(2), 103-116.

Lessa Filho, R. (2019). Retratos de identificação: a imagem-arquivo como morada da memória. Significação, 46(52), 101-125.

Machado, P. (2013). Imagens que faltam, imagens que restam: a tortura em «Cabra marcado para morrer». Significação, 42(44), 271-293.

Machado, P. (2016). Imagens que restam: a tomada, a busca dos arquivos, o documentário e a elaboração de memórias da ditadura militar brasileira (Tesis Doctoral inédita). Universidade Federal do Rio de Janeiro, Rio de Janeiro.

Machado, P.M. (2017). Trânsito de memórias: tomada e retomada de imagens do exílio durante a ditadura militar brasileira. Significação, 44(48), 202-222.

Motta, R.P.S. (2011). Repressão e resistência no Brasil. Diálogos, 15(2), 331-336.

Nercesian, I. (2006). Organizaciones armadas y dictadura institucional. Fermentum, 16(46), 446-480.

Passerini, L. (2018). Conversations on Visual Memory. Florencia: European University Institute.

Ramos Monteiro, L. (2017). A estética da "fotografia animada» na criação contemporânea: desarquivamento, colocação em movimento, escrutínio analítico, montagem, escuta e projeção de imagens de arquivo. Significação, 44(47), 239-257.

Risso Sales, C., y Martins Filho, J.R. (2018). The Economist and Human Rights Violations in Brazil During the Military Dictatorship. Contexto Internacional, 40(2), 203-227.

Sánchez-Biosca, V. (2021). La muerte en los ojos. Qué perpetran las imágenes de perpetrador. Madrid: Alianza.

Sekula, A. (1986). The Body and the Archive. October, 39, 3-64.

Zelizer, B. (2010). About to Die. How Images Move the Public. Nueva York: Oxford University Press. 